"This is the peer reviewed version of the following article: Waller, Martyn and Early, Richard (2015) Vegetation dynamics from a coastal peatland: insights from combined plant macrofossil and pollen data. Journal of Quaternary Science, 30(8), pp. 779-789. ISSN (print) 0267-8179, which has been published in final form at http://dx.doi.org/10.1002/jqs.2812. This article may be used for non-commercial purposes in accordance with Wiley Terms and Conditions for Self-Archiving."

\title{
Vegetation dynamics from a coastal peatland: insights from combined plant macrofossil and pollen data
}

Martyn Waller and Richard Early

Department of Geography and Geology, Kingston University, Penrhyn Road, Kingston upon Thames, Surrey, KT1 2EE, UK.

\section{Abstract}

This paper reports the results of plant-macrofossil investigations from a peat layer buried within coastal alluvium at the Caburn, a site adjacent to the English chalkland. The data collected are compared against a previously published mid-Holocene pollen sequence with the macrofossil record providing greater taxonomic resolution and establishing a local presence for many taxa. Alnus glutinosa pollen is abundant and Alnus macrofossils are recorded continuously over a $c$. $3000 \mathrm{cal}$ year period. Fluctuations in the number of Alnus propagules and the presence of seeds of light-demanding herbaceous plants suggest that regeneration occurred at a local-scale, a process which is likely to have been promoted by a rising water-table and sediment consolidation. Taxus baccata macrofossils were also recovered indicating that the high pollen values previously reported may be the result of yew being present within the wetland area. The Tilia macrofossils establish the presence nearby of T. cordata, T. x europaea and T. platyphyllos. High pollen values for Quercus, Tilia and Alnus coincide with the occurrence of their anthers. Deposition within inflorescences is therefore likely to have been an important mode of pollen delivery. The usefulness of both techniques in studies that utilize peats derived from fen carr vegetation are discussed.

KEYWORDS: chalkland vegetation history; Alnus glutinosa; Tilia; Taxus baccata; midHolocene;

\section{Introduction}

Poor taxonomic resolution is a well recognised limitation of pollen-based studies of vegetation history. Particular problems arise where the sediment utilised derives from eutrophic fen environments, as many of the herbaceous pollen types (e.g. Rumex, Apiaceae, Poaceae) could originate from either the local peat forming vegetation or vegetation growing on areas of dry land. With wood remains common in such deposits, the wetland/dry land origin of pollen derived from tree taxa tolerant to waterlogging (e.g. Quercus and Fraxinus excelsior) can also be unclear. In south-east England these problems are acute as, due both to the absence of natural lakes and scarcity of oligotrophic peats, most of the data on Holocene vegetation history originate from eutrophic peats buried within areas of coastal and riverine alluvium (e.g. Godwin 1962; Waller 1993, 1994a; Waller and Schofield 2007; Branch et al. 2012). 
One such study examined the mid-Holocene vegetation history of the chalkland through a pollen sequence constructed from a peat deposit buried in alluvium at the foot of the steep scarp slope of the Caburn, part of South Downs in East Sussex (Waller and Hamilton 2000). Here, as at other valley sites within the chalkland area of southern England (Waton 1982) the problems associated with taxonomic precision were exacerbated by poor pollen preservation. As a consequence of these difficulties a number of issues were left unresolved. Notably, with Tilia pollen abundant, these included which species of lime were present. In England Tilia cordata occurs on a range of soil types, while T. platyphyllos is regarded as native on calcareous soils (Preston et al. 2002) and extant populations occur on the South Downs in West Sussex (Abraham and Rose 2000). High Taxus baccata values were found after c. 5400 cal a BP. As Taxus forms pure woodland stands on the chalk today this pollen was assumed by Waller and Hamilton (2000) to be derived from the dry land. However, a number of subsequent studies (Deforce and Bastiaens 2007; Branch et al. 2012) have demonstrated that yew was present on peat in alluvial environments around the southern North Sea during the mid-Holocene and this may also have been the case at the Caburn. Increases in herbaceous pollen were used to infer phases of woodland disturbance on the slopes of the Caburn from as early as $c .6350 \mathrm{cal}$ a BP. The origin of much of this pollen is nevertheless ambiguous and in some cases the increases are accompanied by high values for aquatics suggesting they may be indicative of changes in the wetland environment.

Problems relating to the poor taxonomic precision and the uncertain (regional or local) origin of pollen grains can be addressed by combining pollen and plant macrofossil investigations from sites (Birks and Birks 2000). The macrofossils recovered from the pollen washings in the original study indicated that plant macrofossils were abundant and suggested that analysis of the original cores (which remained in good condition) would enable the issues outlined above to be addressed. This paper reports the results of this analysis which, with the macrofossil investigation undertaken at a high resolution, can be compared directly against the results of the original pollen study.

\section{The site and the previous investigations}

Above the Chalk bedrock, the alluvial sequence of the Glynde valley at the base of the Caburn (Fig. 1) consists of a thin layer of organic silt overlain by a woody detrital peat (at least $2.88 \mathrm{~m}$ thick) and grey silty clays and sandy silts. The site for palaeoecological investigation was selected so as to maximise the pollen derived from the adjacent dry land while including the deeper layers of the peat. The minimum distance between this site and the edge of dry land will have increased through time though will not have exceeded $20 \mathrm{~m}$ during peat formation. A summary of the lithology of the sediments used in this investigation is provided (Table 1).

Radiocarbon dating indicated (Waller and Hamilton 2000) that, at the cored site, peat accumulation commenced c. $7100 \mathrm{cal}$ a BP and ceased c. $3750 \mathrm{cal}$ a BP (see Fig. 2). The sediment accumulation rate declines up the sequence. The $5 \mathrm{~cm}$ slices used for the macrofossil analysis accumulated over $c .42 .5 \mathrm{cal}$ years at the base, rising to $c .73$ cal years below the upper contact of the peat.

Waller and Hamilton (2000) defined a series of local pollen assemblage zones, which are used here as the basis for comparing the pollen and macrofossil sequences. Alnus glutinosa values are very high (up to 65\% Total Land Pollen - TLP) and consequently Alnus was removed from the pollen sum. After an initial zone (LPAZ-1a) in which high Cyperaceae and 
Quercus values are recorded, tree and shrub pollen dominates until c. $6300 \mathrm{cal}$ a BP. The main taxa are Alnus glutinosa, Quercus, Tilia and Corylus avellana-type. Ulmus and Fraxinus excelsior also attain values $>5 \%$ TLP-Alnus. LPAZ-2 is characterised by high herbaceous pollen values notably Poaceae, Cyperaceae and the Asteraceae. A number of shrub taxa associated with the Chalk today are also regularly recorded including Taxus baccata, Juniperus communis and Cornus sanguinea. This zone was divided into three subzones as a consequence of a phase (LPAZ-2b) with unusually high Tilia values. The dominant taxa in LPAZ-3 (from c. 5400 cal a BP) are Alnus glutinosa, Quercus, Corylus avellana-type and Taxus baccata. Increases in Cyperaceae and Poaceae pollen occur in the upper part of the sequence.

Ordination of the pollen data offers little extra information, as although the local pollen assemblage zones are reasonably distinct, the herbaceous taxa are not well grouped. Microscopic charcoal was sparse and not counted.

\section{Methods}

The material used for the macrofossil analysis was collected using a Russian corer in 1998 and subsequently stored in the dark at $3-4^{\mathrm{O}} \mathrm{C}$. The cores were divided into $5 \mathrm{~cm}$ slices which, when intact, had a volume of $40 \mathrm{~cm}^{3}$, though this material had previously been sampled for pollen analysis and loss-on-ignition $\left(2 \mathrm{~cm}^{3}\right)$ and material had been extracted for four AMS radiocarbon dates $\left(4-6 \mathrm{~cm}^{3}\right)$. Samples were left to disperse in water, though many also required a period of gentle heating after the addition of $5 \% \mathrm{KOH}$, before being passed through sieves of respectively $2 \mathrm{~mm}, 1 \mathrm{~mm}, 0.5 \mathrm{~mm}$ and $0.2 \mathrm{~mm}$ mesh size.

The residues were examined under a stereomicroscope and the plant propagule and vegetative remains extracted. The latter included wood (only fragments $>0.5 \mathrm{~mm}$ in diameter were identified), buds/budscales, catkin fragments, leaf fragments, glumes and rhizomes. Molluscan remains were also recovered from the base of the peat and foraminifera from the clayey silt immediately overlying the peat. For the quantification of the propagules; where seeds were present within fruits (e.g. for Alisma plantago-aquatica, Carex) only the fruits were counted. Where broken remains were recovered the counts are based on the minimum number of individuals present. As it was only possible to examine a proportion of the $0.2 \mathrm{~mm}$ fraction from each sample $\left(c .5 \mathrm{~cm}^{3}\right)$ the remains extracted (Juncus spp., Typha, Salix and Epilobium seeds, anthers, and the foraminifera) should be regarded as minimum values. Vegetative remains, where the number of individuals recovered cannot be consistently counted, are problematic to quantify (Birks 2014). In this study, the wood and bud remains disintegrated during processing and therefore the vegetative remains are recorded only as present/absent. Mosses (the leaves of which were also present in the finest fraction) are presented using an ordinal abundance scale (Dickson 1986).

Plant remains were identified primarily using reference material held at the Department of Geography and Geology at Kingston University complemented by reference texts notably Cappers et al. (2006) for propagules, Schweingruber (1978) for wood, Tomlinson (1985) for buds/budscales and Smith (2004) for mosses. The diagrams of fossil remains were constructed using the program TILIA*GRAPH (Grimm 2011).

Nomenclature for the propagules follows Cappers et al. (2006), plant taxonomic nomenclature follows Stace (2010) and Smith (2004), and nomenclature for mollusca and foraminifera follow Anderson (2005) and Murray (1979) respectively. 


\section{Results}

Macrofossils: general considerations

Waller and Hamilton (2000) reported on the poor state of pollen preservation in the Caburn sequence. In contrast, macrofossil preservation was generally good even from the outer sections of core material. The variation in preservation which was observed is therefore likely to be related to taphonomic processes operating within the depositional (fen carr) environment; some macrofossils are likely to have fallen directly into depressions/pools (see the Discussion), while others were washed into such areas after a delay or accumulated in drier areas. As a result some bias towards both the easier to identify and more robust remains, such as the fruits of Eupatorium cannabium, is inevitable.

The variable but considerable presence of wood remains (in this case ranging up to $3 \mathrm{~cm}$ in diameter) imposes a severe, though largely unacknowledged, constraint on plant macrofossil analyses from coastal/floodplain peat deposits. They result in a high degree of heterogeneity between the content of samples. In such circumstances the number of propagule remains recovered is not made comparable by standardising either by the initial sample size or by the period over which they accumulated. This is demonstrated in the macrofossil summary diagram from the Caburn (Fig. 2) where the samples with low abundance show a close correspondence to the presence of large fragments of wood, irrespective of such data manipulation. Significantly, this lack of comparability limits numerical data-analysis.

The results of the macrofossil investigations (with propagule numbers standardized to a volume of $40 \mathrm{~cm}^{3}$ ) are presented in Fig. 3 with the palynological data alongside, where equivalent taxa were recorded. Table 2 details the molluscan and foraminiferal remains. With emphasis here on the comparison between the pollen and macrofossil records in terms of representation and taxonomic precision and the local or regional origin of individual taxa, the results are detailed under life-form/ecological groupings.

\section{Trees (Fig. 3a)}

Both the pollen and fruits of Betula were recovered in small quantities from all three zones (Fig. 3a). Betula fruits are wind dispersed and with birch likely to be over-represented in both records it appears not to have been common in either the dry or wetland vegetation around the site during peat formation. Ulmus and Fraxinus excelsior are also recorded both as pollen and macrofossils. For Fraxinus, pollen representation and the presence of bud/budscales suggest it occurred in greater abundance/closer to the site during LPAZ-1 and 2. Although associated with calcareous soils and represented in the pollen record, neither Acer campestre (which unusually is consistently recorded) or Fagus sylvatica, were recorded as macrofossils.

Quercus is well represented in both records with the macrofossil remains (bud/budscales, wood, fruits, involucres and anthers) indicating oak was present nearby throughout peat formation. Of the budscales recovered most belonged to Quercus, with a maximum of 80 recorded from 680-675 cm. This can be attributed to the number of Quercus budscales produced per bud, more than 20 compared with 2-4 for Alnus glutinosa (Tomlinson 1985). More significantly, the very high pollen values (73\% TLP-Alnus) at the top of LPAZ-1a coincide with the presence of oak anthers. 
A variety of Tilia remains (bud/budscales, wood, fruits, seeds, flowers and anthers) were also recovered, the occurrences of which correspond well with the high Tilia pollen values in LPAZ-1 and particularly LPAZ-2. Again, very high Tilia pollen values (maximum 43\% TLPAlnus), along with the presence of clusters of pollen grains (Fig. 3a), coincide with the presence of anthers and flowers with anthers. A total of 220 Tilia fruits were recovered. $T$. cordata and $T$. platyphyllos along with the hybrid $T$. x europaea appear to be represented, which together with the presence of immature fruits/infertile fruits and shrinkage (the fossil fruits are smaller than modern material), has resulted in an assemblage difficult to classify. The fruits of $T$. cordata (106) were distinguished on the basis of their thin-walls, relatively small size and shape, while the T. platyphyllos (21) fruits are relatively large and ribbed (see Supporting Information). The T. x europaea (38) fruits are intermediate in character. The immature and/or infertile fruits have been designated 'Tilia' fruits (55). Pigott (1991) indicates that most fruits of $T$. cordata (the smallest of the fruits) fall within $100 \mathrm{~m}$ of the parent tree. This, along with the abundance and variety of remains, demonstrates that at least during LPAZ-2 Tilia grew very close to the site and therefore the wetland edge.

Given the abundance of Alnus glutinosa pollen in the Caburn sequence it is not surprising that Alnus remains also dominate the macrofossil record. The fruits are particularly abundant with three samples containing over 150. Alnus anthers and catkin fragments, many of which contained anthers (see Supporting information) are also common, lending weight to previous suggestions that the very high frequencies of Alnus pollen often encountered in fen carr deposits (e.g. $>60 \%$ TLP) result in part from the deposition of pollen in inflorescences (Waller 1993). With the fruits and cones deposited almost continuously, it appears that Alnus, after the initial stages of peat formation, grew at or close to the site for some 3000 cal years.

\section{Small trees/shrubs and the Rosaceae}

Three Taxus baccata seeds and one fragment of wood were recorded from the pollen zone with high yew pollen values (LPAZ-3). Taxus pollen is said to be poorly dispersed (Deforce and Bastiaens 2007), while the potential for yew macrofossils to be missed, even when present within the wetland, is highlighted by the study of Branch et al. (2012); none were recovered despite high pollen values, large samples being taken and yew remains being recorded from an earlier test pit. The combined pollen-macrofossil evidence from the Caburn then demonstrates a presence nearby, and while it is not conclusive evidence for, it seems plausible that Taxus grew on the peat surface.

Unusually for the mid-Holocene in south-east England Juniperus communis pollen was recorded in the upper part of LPAZ-1 and during LPAZ-2 (Fig. 3b). Macrofossil remains closely resembling the rather indistinct Juniperus stones and their associated resinous growths were also recovered from LPAZ-2. Juniperus is suggestive of the expansion of scrub after woodland clearance, with such activity potentially focussed on the gentler slopes immediately above the site (Waller and Hamilton 2000).

In contrast to the pollen, which was only sparsely recorded from the upper part of the sequence, Ilex aquifolium macrofossils (wood and endocarps) were recovered from all three pollen zones. Although it is often considered intolerant of both base-rich and waterlogged soils, holly has been recorded on carboniferous limestone and in the drier parts of fen carr (Peterken and Lloyd 1967), with Ilex pollen recorded in some abundance from a few fen carr sites (see Deforce et al. 2014). At the Caburn, the regular occurrence of macrofossils including wood, strongly suggests a presence within the wetland area. 
For Rhamnus cathartica and Corylus avellana macrofossil occurrence does not correspond with the highest pollen values (in LPAZ-1b). This can be attributed to abundance of large wood fragments in this zone. Both taxa are tolerant of waterlogging and their presence at the wetland edge is unsurprising. Corylus appears to have occurred close to the site throughout peat deposition, though is notably less well-represented in the macrofossil record (with in addition to fruits, only one budscale and one wood fragment recorded) than the other taxa which dominate the pollen record (Quercus, Alnus glutinosa and Tilia).

Salix was recorded in most of the pollen samples from the Caburn, though at very low frequencies (generally < 1\% TLP-Alnus). The macrofossil remains give a rather different impression of Salix abundance with buds/budscales, wood, fruits, seeds and leaf fragments recorded throughout LPAZ-2 and 3. The latter demonstrate an on-site presence and confirm the potential for Salix to be heavily under-represented in pollen diagrams from fen carr deposits (e.g. Bush 1993; Waller 1994b).

The large endocarps of Cornus sanguinea were regularly recorded during LPAZ-1 and 2. C. sanguinea is therefore likely to have occurred adjacent to the site for an extended period, though on the drier soils (Preston et al. 2002). While $C$. sanguinea macrofossils are absent during LPAZ-3, the pollen continues to be regularly recorded suggesting a continued dry land presence.

The poor state of pollen preservation prevented the separation of much of the Rosaceae pollen recorded in the Caburn sequence. Such pollen occurs throughout the sequence with values of 5\% TLP-Alnus in LPAZ-2 suggesting a local presence. Given their occurrence in modern Alnus woodland (Rodwell 1991); the macrofossil record suggests that much of this pollen derives from the shrubs Crataegus and Prunus spinosa in LPAZ-1, while in LPAZ-3 Rubus seems the most likely candidate. All three taxa are recorded as macrofossils in LPAZ2 .

Both the pollen and seeds of Sambucus nigra were recovered from LPAZ-2. S. nigra is a constituent of modern fen woodland and macrofossils are frequently recorded in investigations from floodplain sites (e.g. Branch et al. 2012; Deforce et al. 2014). The presence of Viburnum opulus seeds suggests that the poorly preserved Viburnum pollen recorded largely derives from this wetland species rather than the chalkland shrub Viburnum lantana.

A single pollen grain of Buxus sempervirens was recorded from the Caburn sequence. While this is insufficient to demonstrate box occurred in southern England in the mid-Holocene, with Buxus pollen also recorded from northern France at this time (Domenico et al. 2012), such a presence is plausible. No Buxus macrofossil remains were recovered.

\section{Herbaceous taxa}

A number of herbaceous taxa are only represented in the pollen record. Most are recorded sporadically and/or at low frequencies, though they include wetland taxa such as Thalictrum, Lysimachia vulgaris, Chrysosplenium, Filipendula, Lotus, Lythrum portula, Gentianellla campestris-type and Stachys-type. As all are likely to have been growing nearby, their macrofossil absence probably in part reflects the small sample size. Others (Limonium, Armeria maritima, Glaux maritima, Plantago maritima and Artemisia-type) are associated 
with brackish conditions and occur at the transition to and in the upper silty clays (in LPAZ3d). A few, notably Cynoglossum, Sanguisorba minor, Plantago media, Papaver rhoeas, are likely to have been derived from open and disturbed dry habitats on the adjacent Chalk. The only unambiguously dry land herbaceous taxa regularly recorded in the pollen record (and not as a macrofossil) was Plantago lanceolata and pollen frequencies for this taxon only exceed 1\% TLP-Alnus in LPAZ-2c and 3c/d.

Conversely a few herbaceous taxa are recorded as macrofossils while their palynological equivalent is absent (Fig. 3c). These include Persicaria, 27 fruits of which were recovered in LPAZ-2c, and rare Viola, and Epilobium seeds. With the Persicaria, low pollen production and limited dispersal, $P$. hydropiper is for example sometimes cleistogamous (Timson 1966), provide likely explanations. $P$. hydropiper is found in the margins of water and occurs along woodland rides. P. maculosa and P. lapathifolia are usually associated with disturbed land but also grow on exposed mud with Simmonds (1945) noting the presence of P. lapathifolia in fens and salt-marshes in North Germany. Also included in this category are taxa the pollen of which is not normally preserved (Juncus and Luzula). Juncus articulatus and J. effusus seeds occur immediately prior to the end of peat formation (Fig. 3d). Both are tolerant of brackish conditions (Preston et al. 2002), while the seeds of the saltmarsh taxon J. gerardi are abundant in the upper silty-clays. J. inflexus, which is recorded in LPAZ-2, is associated with base-rich soils and occurs in both herbaceous fens and open woodland. Luzula sylvatica, recorded from LPAZ-3, is likely to have grown in shaded habitats in drier areas (Rodwell 1991).

The small sample size used in the macrofossil investigations probably explains the mismatch between the common pollen and comparative rare macrofossil occurrence of the Brassicaceae, Lythrum salicaria, Scrophulariaceae and Rubiaceae all of which are likely to have been growing in the wetland. Mercurialis perennis pollen is regularly recorded and, as it is also present as macrofossil, is likely to have occurred in drier shaded areas close to the site alongside L. sylvatica. Urtica, Rumex, Caryophyllaceae, Potentilla and Solanum dulcamara are well-represented in both records, though as would be expected their macrofossil occurrence is more erratic. Where greater taxonomic precision is available (e.g. Urtica dioica, Rumex cf cripus, Lychnis flos-cuculi) the macrofossil record is useful in showing that most of the pollen is likely to have been derived from taxa growing within the wetland.

Three herbaceous taxa (Mentha/Origanum, Eupatorium cannabinum and Sium latifolium) are particularly well represented as macrofossils. Mentha-type pollen is only occasionally recorded while the fruits of Lycopus europeus and Mentha are comparatively common. The former is associated with a variety of wet habitats and the latter almost certainly derive from the common fen taxa Mentha aquatica, though the fruits cannot easily be separated from other Mentha species or the chalkland herb Origanum. Most of the Solidago virgaurea-type pollen seems to have been derived from Eupatorium cannabinum, the seeds of which are abundant in LPAZ-2a. This species is found in a range of base-rich moist habitats including wet woodland (Preston et al. 2002) though seed production is likely to be associated with areas where the canopy is relatively open. Apiaceae pollen and the fruits of Sium latifolium occur throughout LPAZ-2 and 3. Sium is associated with alkaline conditions and occurs in a variety of tall-herb rich fen habitats often growing as an emergent. Unlike many of the other herbaceous taxa recorded it is intolerant of shade (Hill et al. 2004).

The macrofossil occurrence of Carex closely corresponds to the Cyperaceae pollen record suggesting that the pollen largely derives from wetland taxa. Both tussock (e.g. Carex 
paniculata) and mat forming (e.g. Carex acutiformis) sedges commonly occur in modern Alnus dominated fen carr. The only other member of the Cyperaceae it was possible resolve further taxonomically in the macrofossil record, Scirpus sylvaticus, is associated with wet woodland (Preston et al. 2002). In contrast, while Poaceae macrofossils were regularly recorded their occurrence does not match well with Poaceae pollen abundance. This does not just apply to the seeds, glumes were recorded during a period (LPAZ-3b/c) when Poaceae pollen frequencies are consistently $<5 \%$ TLP-Alnus. The source area for the Poaceae pollen may therefore be comparatively large, though whether it mostly derives from wet or dry habitats is still unclear.

Aquatics

Aside from Sparganium emersum-type, the pollen of aquatics is scarce if well distributed throughout the Caburn sequence. In contrast the macrofossils are generally unevenly distributed but often occur in some abundance (Fig. 3d). With Ranunculus wet or dry taxa may have contributed to the pollen record, though given that all are insect pollinated underrepresentation is likely. $R$. flammula macrofossils were recorded from the upper contact of the peat, while subgenus Batrachium fruits occur in some abundance in LPAZ-2. The latter suggest the presence of standing water, though some taxa (e.g. $R$. hederaceus) occur on the edges of shallow and/or impermanent waterbodies, a habitat that might also contain Hydrocotyle vulgaris, Callitriche and Alisma plantago-aquatica. All of these taxa are also shade tolerant (Grime et al. 2007). A. plantago-aquatica, which produces flowers on long stalks well above water-level, is exceptional in that the pollen and macrofossil records closely coincide suggesting that pollen occurrence indicates a local presence. A. plantago-aquatica is characteristic of sites with a fluctuating water-table (Grime et al. 2007). The presence of Typha fruits along with the high Sparganium emersum-type (which includes Typha angustifolia) pollen values in LPAZ-2 may indicate an expansion nearby in emergent vegetation. However, the coincidental abundance of Artemisia-type pollen, which is most likely to have been derived from the salt marsh taxon Seriphidium maritimum, suggests the presence of material inwashed as a result of inundation. Deforce et al. (2014) recovered the remains of such brackish indicators well above usual the tidal node, which was attributed to deposition during spring-tides or storm surges.

\section{Mosses}

Fifteen moss species were identified (Fig. 3d). Many have previously been recorded from Holocene coastal peats (Dickson 1973). Four species are regularly recorded in LPAZ-1 (Brachythecium rutabulum, Homalothecium sericeum, Neckera complanata and Hypnum cupressiforme). All are associated with woodland and, as is consistent with the abundant wood remains, occur as epiphytes. B. rutabulum and $N$. complanata are shade tolerant, while $H$. sericeum and $H$. cupressiforme prefer lightly shaded conditions (Blockeel et al. 2014). Of the minor taxa, Bryum pseudotriquetum and Campyliadelphus elodes, are associated with light shade/open conditions, including fens. In contrast, Thamnobryum alopecurum is shade tolerant and grows in abundance in woodland over Chalk (Blockeel et al. 2014) and is of particular interest as it was recorded at the very base of the sequence.

The abundance and diversity of mosses is greatest in LPAZ-2. Again the main species (which now include Amblystegium serpens) are associated with wet woodland. Most are likely to have been growing on wood, with Ulota crispa commonly occurring on Salix and Mnium hornum associated with dead wood on calcareous soils (Blockeel et al. 2014). Calliergonella cuspidata 
has a wide ecological amplitude while Oxyrrhynchium hians occurs on the ground in woodland over Chalk (Blockeel et al. 2014). Mosses were least abundant in LPAZ-3, though taxa indicative of wet woodland (A. serpens and $B$. rutabulum) continue to be regularly recorded and $H$. cupressiforme (which will occur on dead wood) is common immediately prior to the end of peat formation.

\section{Mollusca and Foraminifera}

Nine terrestrial gastropod taxa were recovered from the basal sample (Table 2). All are tolerant of shaded environments and consistent with presence of woodland/scrub. The remains of Carychium are most abundant. Carychium tridentatum is frequent in deciduous woods and well-shaded places (Preece and Bridgland 1998). Discus rotundatus, Clausilia bidentata, Aegopinella nitidula, A. pura are associated with moist locations, while Vitrea crystalline, Trochulus hispidus and Cochlicopa sp. occur in wetter environments including fens (Kerney and Cameron 1979). Pomatias elegans occurs in shade, but is associated with loose friable calcareous soils (Kerney and Cameron 1979). A single specimen of Discus rotundatus was recovered from the overlying sample.

Foraminifera were recovered from the clayey silts which overlie the peat (Table 2).

Trochammina inflata and Elphidium williamsoni are indicative of hyposaline and inter-tidal sand flat environments respectively (Horton and Edwards 2006) and along with the remains of Juncus gerardi confirm a marine/brackish origin for this deposit. The continued occurrence of macrofossils of freshwater plants (e.g. Alnus glutinosa and Salix) in this deposit is therefore likely to indicate the presence of reworked material.

\section{Discussion}

The mid-Holocene vegetation of the Chalk

Reconstructing the vegetation history of the Chalk was the primary aim of the original investigations at the Caburn, with the pollen site selected so as to maximise the extra-local pollen component (sensu Jacobson and Bradshaw 1981). Waller and Hamilton (2000) concluded that the slopes above the site remained well-wooded throughout the mid-Holocene, with communities analogous to modern Fraxinus excelsior-Acer campestre-Mercurialis woodland (Rodwell 1991) present. Such woodland is typically found on calcareous mull soils.

The macrofossil investigations provide some extra detail as to the likely composition of this woodland. T. platyphyllos usually grows on freely draining soils and occurs on Chalk slopes. It is therefore one of the few taxa, along with Cornus sanguinea, recorded as a macrofossil in the Caburn sequence which is more certainly associated with dry woodland.

Rodwell (1991) notes that transitions between fen carr and dry deciduous woodlands are often gradual, masking discontinuities in substrate composition. Quercus is likely to have been favoured by moister and heavier soils and therefore to have occurred in such a wet-dry ecotone along with other taxa tolerant of waterlogging (e.g. Ilex aquifolium, Crataegus, Merculiaris perennis, Rubus and Luzula sylvatica). Tilia cordata rarely occurs on soils directly over Chalk (Pigott 1991, 2012). The nearest outcrop of an alternative solid stratum, the Gault (clay), lies c. $1 \mathrm{~km}$ to the south. It is therefore likely to have grown either on clay- 
rich superficial deposits at the base of the slope or at the wetland edge. Interestingly, Pigott (1991) notes the occurrence of $T$. cordata in riverine woodland on the continent.

Tilia cordata and T. platyphyllos have been recorded in close association from modern situations (e.g. Pigott 1969, 1991) and previously from macrofossil investigations of alluvial deposits (e.g. Kelly and Osborne 1965; Deforce et al. 2014). Hybridisation between these taxa appears to have a long history, as demonstrated by the presence of $T$. x europaea fruits in the Caburn record and suggested from pollen morphology in previous studies (Godwin 1975; Pigott 1991, 2012). An effective isolating mechanism must therefore exist. T. platyphyllos flowers $c$. 15 days earlier than T. cordata and Pigott $(1991,2012)$ indicates that the hybrids flower simultaneously or at an intermediate time.

The fossil representation of a number of the taxa recorded in the Caburn sequence declines up the sequence. This in itself is likely to indicate a preference for the drier parts of the ecotone or the Chalk and to reflect the retreat of such areas away from the site as the wetland area expanded through time (see Waller 1994c; Deforce et al. 2014). In the pollen record this phenomenon is evident for Ulmus, Fraxinus excelsior, Tilia, Corylus avellana, Rhamnus catharticus and Hedera helix, while in the macrofossils it is most apparent for Tilia spp., Cornus sanguinea and Prunus spinosa.

While indicating that the pollen source area remained well-wooded, Waller and Hamilton (2000) detail evidence for a number of woodland disturbance phases. High frequencies of herbaceous pollen in LPAZ-2a, 2c and 3c were attributed to clearance, fluctuating tree pollen values in LPAZ-2 to woodland management and high Taxus baccata pollen frequencies in LPAZ-3a and 3b to the establishment of secondary woodland. The macrofossil evidence offers little support for such interpretations. The increases in herbaceous pollen occur in types with an ambiguous environment of origin, but which now can be shown to coincide with the local presence of wetland taxa notably Eupatorium cannabium, Rumex crispus, Sium latifolium and Carex. In addition, Taxus baccata may have been growing locally. That most of the tree and herbaceous types well-represented in the pollen record occur as macrofossils confirms, as would be expected for a wooded site, that the pollen source area for the Caburn sequence is small. Modern pollen studies of Alnus dominated fen carr (Bunting et al. 2005) indicate a relevant source area (sensu Sugita 1994) in the order of 50-150 m. Therefore while the occurrence of Juniperus communis and the pollen of herbs such as Sanguisorba minor hint at the occurrence of open habitats on the Chalk, their presence and changes in extent are masked by the surrounding woodland.

\section{Wetland vegetation dynamics}

The Caburn macrofossils primarily provide information on the nature and dynamics of the wetland environment. The mid-Holocene sediments at the base of the Caburn are the product of a high water-table (the minerotrophic peat) or are waterborne (the clastic component). The accumulation of $3 \mathrm{~m}$ of such sediment requires the creation of accommodation space, which ultimately in such coastal locations is provided by sea-level rise, though sediment consolidation and compaction can also be important (e.g. Horton and Shennan 2009). The sea-level curves produced for the southern North Sea indicate peat formation at the Caburn commenced at the end of a long period of rapid sea-level rise, with a notable decline in the rate of rise occurring around $6000 \mathrm{cal}$ a BP (see for example Vink et al. 2007; Waller and Long 2010). The latter is probably reflected in the up-sequence decline in the rate of peat 
accumulation, though this is also likely to have been influenced by differential compaction of the upper layers following the deposition of the overlying clayey silts.

With the basal organic sediment highly humified, paludification appears to have commenced prior to the site becoming permanently waterlogged. LPAZ-1a, the plant macrofossils and molluscs all suggest the development of woodland in which taxa tolerant of waterlogging predominated (with Quercus and shrubs including Corylus avellana, Crataegus and Prunus spinosa). Herbaceous taxa indicative of wet conditions (e.g. Mentha, Carex) are also present in the macrofossil record and along with the mollusc Trochulus hispidus are probably an indication of gaps left as species less tolerant of such conditions were eliminated. As the water-table continued to rise Alnus glutinosa dominated woodland became established.

From the beginning of LPAZ-1b until the deposition of the clayey silts (LPAZ-3d) Alnus glutinosa macrofossils are continuously, if variably, recorded. Other taxa associated with modern Alnus dominated communities (the Alnus glutinosa-Carex paniculata and Alnus glutinosa-Urtica dioica woodlands of Rodwell 1991) notably Salix, Urtica dioica and Carex also occur regularly as macrofossils. With fen carr a component of the wetland vegetation over an extended period, this community must have undergone internal regeneration. Under stable conditions, as a result of producing large quantities of organic material, Alnus dominated vegetation might be expected to outgrow the water-table, leading to the establishment of species with a preference for drier conditions (e.g. Walker 1970). In coastal situations such as the Caburn the long-term maintenance of fen carr is, however, likely to be linked to the continued creation of accommodation space and therefore allogenically driven. During the earlier stages of peat formation at the Caburn (LPAZ-1), the combination of rising water-levels and rapid sediment accumulation will have resulted in trees becoming moribund, without surfaces becoming sufficiently dry to enable the establishment of successor communities (Rodwell 1991). The collapse of trees would then have promoted a further phase of development. As the depth of peat increased (LPAZ-2 and 3) consolidation is likely to have become increasingly important in initiating regeneration. As described by Lambert (1951), the weight of trees over unconsolidated surfaces produces subsidence leading to the development of pools and eventually tree death. The up-sequence decline in the quantity of wood remains, despite the continued abundance of Alnus fruits and cones, may reflect a decline in the size of trees (related to their longevity and weight) as consolidation became increasingly influential, with the increasing peat depth also giving shallower rooted species a competitive advantage (see below).

The ability to identify such regeneration phases in palaeoecological records is dependent upon the temporal and spatial scales over which they occur. With local variations in the stability of the surface (influenced by factors such as the depth to bedrock and the composition of the peat), neither the simultaneous dieback of trees over large areas or regular cycles would be expected. This probably explains why in coastal/floodplain situations, where fen carr vegetation is likely to have been extensive, regeneration phases are difficult to discern in pollen records which show the long-term persistence of Alnus glutinosa (e.g. Waller 1993, 1994a). Pollen data may not be sensing the vegetation at an appropriate spatial scale, particularly as local openings are likely to be accompanied by an increase in the pollen source area. At the Caburn, the substantial fluctuations in the number of Alnus glutinosa propagules provide support for phases of decline and regeneration (e.g. low numbers at the LPAZ3a/b boundary and increase in LPAZ-3b). In addition, with high light intensities required for the survival of Alnus seedlings (McVean 1956), increases in herbaceous taxa would be expected following the creation of gaps. Although the number of macrofossils 
recorded is often small and patterns in abundance are not always evident, light demanding taxa (e.g. Sium latifolium, Persicaria and the moss Campyliadelphus elodes) occur throughout the sequence. The macrofossil data is then consistent with gap creation and regeneration occurring on a small-scale. However, due to the limitations of the technique, the lack of comparability between samples and taphonomic issues, notably the high dispersal capacity of Alnus propagules (Greatrex 1983), it is not possible, unequivocally, to resolve individual phases.

The increases in the macrofossils of aquatics (e.g. Ranunculus subgenus Batrachium, Alisma plantago-aquatica) and semi-aquatic herbs (e.g. Sium latifolium, Lycopus europaeus) in LPAZ-2 and LPAZ-3 appear inconsistent with the drier conditions which might be expected to accompany the slower rate of water-table rise, as indicated by the up-sequence decline in the sediment accumulation rate. This apparent contradiction may be explained by the creation of pools through consolidation, the presence of which is compatible with the occurrence of large numbers of well-preserved macrofossil remains (notably in LPAZ-2). Alternatively, changes in the distribution of watercourses on the floodplain as a result of channel avulsion may periodically have brought open water transitions closer to the site. In addition, the slowdown in the sediment accumulation and/or sediment consolidation is likely to have been responsible for the overall increase in the inorganic content of the sediment, evident in the loss-on-ignition data from the start of LPAZ-3 (Fig. 2). With the height of sediment surface rising more slowly, the floodplain would have been increasingly vulnerable to inundation. This appears to be reflected in the fossil record through the presence of taxa associated with sites flooded with mineral enriched water in LPAZ-3 (e.g. Scirpus sylvaticus, Rodwell 1991). As a consequence, the inwash of pollen and macrofossils from aquatic environments may also have increased (as suspected for LPAZ-2c).

The combined pollen-macrofossil record suggests that Taxus baccata may have occurred within the wetland area during LPAZ-3 (c. 5400 to 4000 cal a BP). If so, then the Caburn adds to the number of sites in the lowland areas adjacent to the southern North Sea where yew was a component of fen carr vegetation (e.g. Godwin 1968; Deforce and Bastiaens 2007; Branch et al. 2012). Dated sequences with high (> 5\% TLP) Taxus pollen values fall into a relative narrow time-window; c. 4900 to $3900 \mathrm{cal}$ a BP for Hornchurch marshes (Branch et al. 2012) and from c. 5600 to $3600 \mathrm{cal}$ a BP for the sites in Belgium and the southern Netherlands (Deforce and Bastiaens 2007). This suggests regional factors underlie both the development and disappearance of the conditions which enabled Taxus to grow in such environments. As discussed by Branch et al. (2012), Taxus is likely to have been favoured by relatively dry and stable conditions. At the Caburn, local establishment in LPAZ-3 ties in with the up-sequence decline in the rate of peat accumulation. Regionally, this was an extended period of peat formation and the shallow rooting habit of yew (Thomas and Polwart 2003) may, for the reasons noted earlier, be the critical factor which enabled Taxus to grow on peat, though as indicated at the Caburn, it seems that trees growing in such situations would still have been subject to regular inundation. The proximity of seed sources is an additional consideration in terms of colonisation. Taxus pollen is recorded at the Caburn consistently, if at low values, from $c .7000 \mathrm{cal}$ a BP and the presence of yew nearby on the Chalk is likely to have enabled colonisation earlier than at many of the other sites and may also explain the apparent absence of yew from similar deposits found adjacent to acid lithologies along the south coast of England (e.g. the Romney Marsh depositional complex). The disappearance of Taxus from such environments can locally be attributed to a number of factors; inundation with marine/brackish water (Hornchurch Marshes, the Caburn) or in the case of some of the continental sites the development of raised bog. Such proximate causes 
can also ultimately be linked to regional environmental changes (see Waller and Grant 2012, Deforce and Bastiaens 2007).

\section{Conclusions}

With a large number of plant macrofossils recovered for the quantity of sediment examined, the investigations described in this paper complement the earlier pollen study and together they provide a detailed picture of the vegetation of the wetland and at the wet-dry ecotone prior to extensive human modification. The occurrence of Tilia platyphyllos fruits shows that the association of this taxon with calcareous soils extends back into the mid-Holocene, as does hybridization between T. platyphyllos and T. cordata. Taxus baccata appears to have occurred in, or at least at the very edge of, the wetland.

The combined investigations from Caburn serve to illustrate the constraints that must be borne in mind when palaeoecological reconstructions are made from peats deposited within coastal/floodplain alluvium. With plant macrofossils analysis, they include a lack of homogeneity in the sediment matrix as a result of the presence of wood remains which compromises the comparability of the samples. In this respect the calculation of wood volume may be more useful than the number of fragments present. In addition, in the southern North Sea region, such studies are likely to be temporally biased towards the midHolocene with later sediments deposited at higher altitudes and invariably highly humified as a result of recent land drainage.

Many of the short-comings of pollen analysis have already been noted. Most importantly, this combined pollen-macrofossil study supports previous work both in terms of the small size of the pollen source area indicated for fen carr sites and the likely wetland origin for many of the herbaceous pollen types generally regarded as indicators of anthropogenic activity. Both must be borne in mind when attempting to reconstruct the vegetation of adjacent dry land areas. The use of pollen data from such situations in land-cover reconstructions is likely, for example, to produce anomalous results if openness is equated with the clearance of dry land areas (see Trondman et al. 2014). The Caburn macrofossil analysis also suggests that deposition via inflorescences is likely to be an important mode of pollen delivery from plant to sediment. Caution is therefore required when interpreting fluctuations in pollen values and using data derived from such deposits in pollen models (e.g. Sugita 2007) that assume aerial transport is the dominant mode.

Acknowledgements. We would like to thank the SEC Faculty at Kingston University for an internship which enabled Richard Early to participate in this research. Professor Donald Pigott provided additional reference material for Tilia and is also thanked for his observations on the Tilia fruits. Tom Ottley helped with the bryophyte identifications, Dr Michael Grant with the seeds and Sarah Wyles identified the molluscan remains. Dr Ed Schofield and Professor Pigott provided valuable comments on a draft of the manuscript. Simon Crust is thanked for his help with the photographs.

\section{References}

Abraham F, Rose F. 2000. Large-leaved limes on the South Downs. British Wildlife 12: 8690 .

Anderson R. 2005. An annotated list of the non-marine mollusca of Britain and Ireland, Journal of Conchology 38: 607-638. 
Blockeel TL, Bosanquet SDS, Hill MO, et al. 2014. Atlas of British and Irish Bryophytes. Pisces Publications, Newbury.

Birks HH, Birks HJB. 2000. Future uses of pollen analysis must include plant macrofossils. Journal of Biogeography 27: 31-35.

Birks HJB. 2014. Challenges in the presentation and analysis of plant-macrofossil stratigraphical data. Vegetation History and Archaeobotany 23: 309-330.

Branch NP, Batchelor CR, Cameron NG, et al. 2012. Holocene environmental changes in the Lower Thames Valley, London, UK: Implications for understanding the history of Taxus woodland. The Holocene 22: 1143-1158.

Bunting MJ, Armitage R, Binney HA, et al. 2005. Estimates of 'relative pollen productivity' and 'relevant source area of pollen' for major tree taxa in two Norfolk (UK) woodlands. The Holocene 15: 459-465.

Bush MB. 1993. An 11400 year paleoecological history of a British chalk grassland. Journal of Vegetation Science 4: 47-66.

Cappers RTJ, Bekker RM, Jans JEA. 2006. Digital seed atlas of the Netherlands. Bakhuis, Groningen.

Deforce K, Bastiaens J. 2007. The Holocene history of Taxus baccata (yew) in Belgium and neighbouring regions. Belgian Journal of Botany 140: 222-237.

Deforce K, Storme A, Bastiaens J. et al. 2014. Middle-Holocene alluvial forests and associated fluvial environments: A multi-proxy reconstruction. The Holocene 24: 1550 1564.

Dickson JH. 1973. Bryophytes of the Pleistocene. Cambridge University Press, London.

Dickson JH. 1986. Bryophyte analysis. In Handbook of Holocene Palaeoecology, Berglund BE (ed). Wiley, Chichester; 627-643.

Domenico FD, Lucchese F, Magri D. 2012. Buxus in Europe: Late Quaternary dynamics and modern vulnerability. Perspectives in Plant Ecology, Evolution and Systematics 14: 354362.

Godwin H. 1962. Vegetational History of the North Downs as seen at Wingham and Froghalt. Veroeffentlichungen des Geobotanischen Institutes der Eidgenoessische Technische Hochschule Stiftung Ruebel in Zurich 37: 83-99.

Godwin H. 1968. Terneuzen and buried forests of the East Anglian Fenland. New Phytologist 67: 733-738.

Godwin H. 1975. History of the British flora, $2^{\text {nd }}$ Edition. Cambridge University Press, Cambridge. 
Greatrex PA. 1983. Interpretation of macrofossil assemblages from surface sampling of macroscopic plant remains in mire communities. Journal of Ecology 71: 773-791.

Grime JP, Hodgson JG, Hunt R. 2007. Comparative Plant Ecology: a functional approach to common British species, $2^{\text {nd }}$ edition. Castlepoint Press, Dalbeattie.

Grimm EC. 2011. TILIA and TILIA*GRAPH. Illinois State Museum, Springfield.

Hill MO, Preston CD, Roy DB. 2004. PLANTATT. Attributes of British and Irish Plants: Status, Size, Life History, Geography and Habitats. Centre for Ecology and Hydrology, Huntingdon.

Horton BP, Edwards RJ. 2006. Quantifying Holocene sea level change using intertidal foraminifera: Lessons from the British Isles. Journal of Foraminiferal Research, Special Publication 40.

Horton BP, Shennan I. 2009. Compaction of Holocene strata and the implications for relative sea-level change on the east coast of England. Geology 37: 1083-1086.

Jacobson GL, Bradshaw RHW. 1981. The selection of sites for palaeovegetational studies. Quaternary Research 16: 80-86.

Kelly M, Osborne PJ. 1965. Two faunas and floras from alluvium at Shustoke, Warwickshire. Proceedings of the Linnean Society London 176: 37-65.

Kerney MP, Cameron RAD. 1979. Land Snails of Britain and North-west Europe. Collins, London.

Lambert JM. 1951. Alluvial stratigraphy and vegetational succession in the region of the Bure valley Broads: III. Classification, status and distribution of communities. Journal of Ecology 39: 149-170.

McVean DN. 1956. Ecology of Alnus glutinosa (L.) Gaertn. V. Seedling Establishment. Journal of Ecology 44: 195-218.

Murray JW. 1979. British Nearshore Foraminiferids. Academic Press, London.

Peterken GF, Lloyd PS. 1967. Ilex aquifolium L. Journal of Ecology 55: 841-858.

Pigott CD. 1969. The status of Tilia cordata and Tilia platyphyllos on the Derbyshire limestone. Journal of Ecology 57: 491-504.

Pigott CD. 1991. Tilia cordata Miller. Journal of Ecology 79: 1147-1207.

Pigott CD. 2012. Lime-trees and Basswoods: a biological monograph of the Genus Tilia. Cambridge University Press, Cambridge.

Preece RC, Bridgland DR. 1998. Late Quaternary Environmental Change in North-West Europe. Chapman and Hall, London. 
Preston CD, Pearman DA, Dines TD. 2002. New Atlas of the British and Irish Flora.

Cambridge University Press, Cambridge.

Rodwell JS. 1991. British plant communities: Volume 1, Woodlands and scrub. Cambridge University Press, Cambridge.

Schweingruber FH. 1978. Microscopic wood anatomy. Swiss Federal Institute of Forestry Research, Birmensdorf.

Simmonds NW. 1945. Polygonum lapathifolium L. Journal of Ecology 33: 132-139.

Smith AJE. 2004. The Moss Flora of the Britain and Ireland, $2^{\text {nd }}$ Edition. Cambridge University Press, Cambridge.

Stace C. 2010. New Flora of the British Isles, $3^{\text {rd }}$ Edition. Cambridge University Press, Cambridge.

Sugita S. 1994 Pollen representation of vegetation in Quaternary sediments: theory and method in patchy vegetation. Journal of Ecology 82: 881-897.

Sugita S. 2007. Theory of quantitative reconstruction of vegetation II: all you need is LOVE. The Holocene 17: 243-257.

Thomas PA, Polwart A. 2003. Taxus baccata L. Journal of Ecology 91: 489-524.

Timson J. 1966. Polygonum hydropiper L. Journal of Ecology 54: 815-821.

Tomlinson P. 1985. An aid to the identification of fossil buds, budscales and catkin-bracts of British trees and shrubs. Circaea 3: 45-130.

Troels-Smith J. 1955. Karakterising af lose jordater. Danmarks Geologiske Undersogelse, Raekke IV, 3, 73 pp.

Trondman K, Gaillard M-J, Mazier F, et al. 2014. Pollen based quantitative reconstructions of Holocene regional vegetation cover (plant-functional types and land-cover types) in Europe suitable for climate modelling. Global Change Biology, doi: 10.1111/gcb.12737.

Vink A, Steffen H, Reinhardt L, et al. 2007. Holocene relative sea-level change, isostatic subsidence and the radial viscosity structure of the mantle of northwest Europe (Belgium, the Netherlands, Germany, southern North Sea). Quaternary Science Reviews 26: 3249-3275.

Walker D. 1970. Direction and rate in some British post-glacial hydroseres. In Studies in the Vegetational History of the British Isles, Walker D, West RG (ed). Cambridge University Press, Cambridge; 117-139.

Waller MP. 1993. Flandrian vegetational history of south-eastern England. Pollen data from Pannel Bridge, East Sussex. New Phytologist 124: 345-369.

Waller MP. 1994a. Flandrian vegetational history of south-eastern England. Stratigraphy of the Brede valley and pollen data from Brede Bridge. New Phytologist 126: 369-392. 
Waller MP. 1994b. The Fenland Project, Number 9: Flandrian environmental change in Fenland. East Anglian Archaeology Monograph 70, Cambridge.

Waller MP. 1994c. Paludification and pollen representation: the influence of wetland size on Tilia representation in pollen diagrams. The Holocene 4: 430-434.

Waller MP, Grant MJ. 2012. Holocene pollen assemblages from coastal wetlands: differentiating natural and anthropogenic causes of change in the Thames estuary, UK. Journal of Quaternary Science 27: 461-474.

Waller, MP, Hamilton S. 2000. The vegetation history of the English chalkland: a midHolocene pollen sequence from the Caburn, East Sussex. Journal of Quaternary Science 15: 253-272.

Waller MP, Long AJ. 2010. The Holocene coastal deposits of Sussex: a re-evaluation. In Romney Marsh: Persistence and change in a Coastal Lowland, Waller MP, Edwards E, Barber L. (eds). Romney Marsh Research Trust, Sevenoaks; 1-21.

Waller MP, Schofield JE. 2007. Mid to late Holocene vegetation and land-use history in the Weald of south-eastern England: multiple pollen profiles from the Rye area. Vegetation History and Archaeobotany 16: 367-384.

Waton PV 1982. Man's impact on the chalklands: some new pollen evidence. In Archaeological Aspects of Woodland Ecology, Bell M, Limbrey S (eds). British Archaeological Reports, International Series 146, Oxford; 75-92.

Figures and Tables 
Figure 1 Location maps and stratigraphy. (A) The Chalk outcrop in England. (B) The Lower Glynde-Ouse valleys and Mount Caburn. (C) Lithostratigraphy of the Glynde valley adjacent to the Caburn.
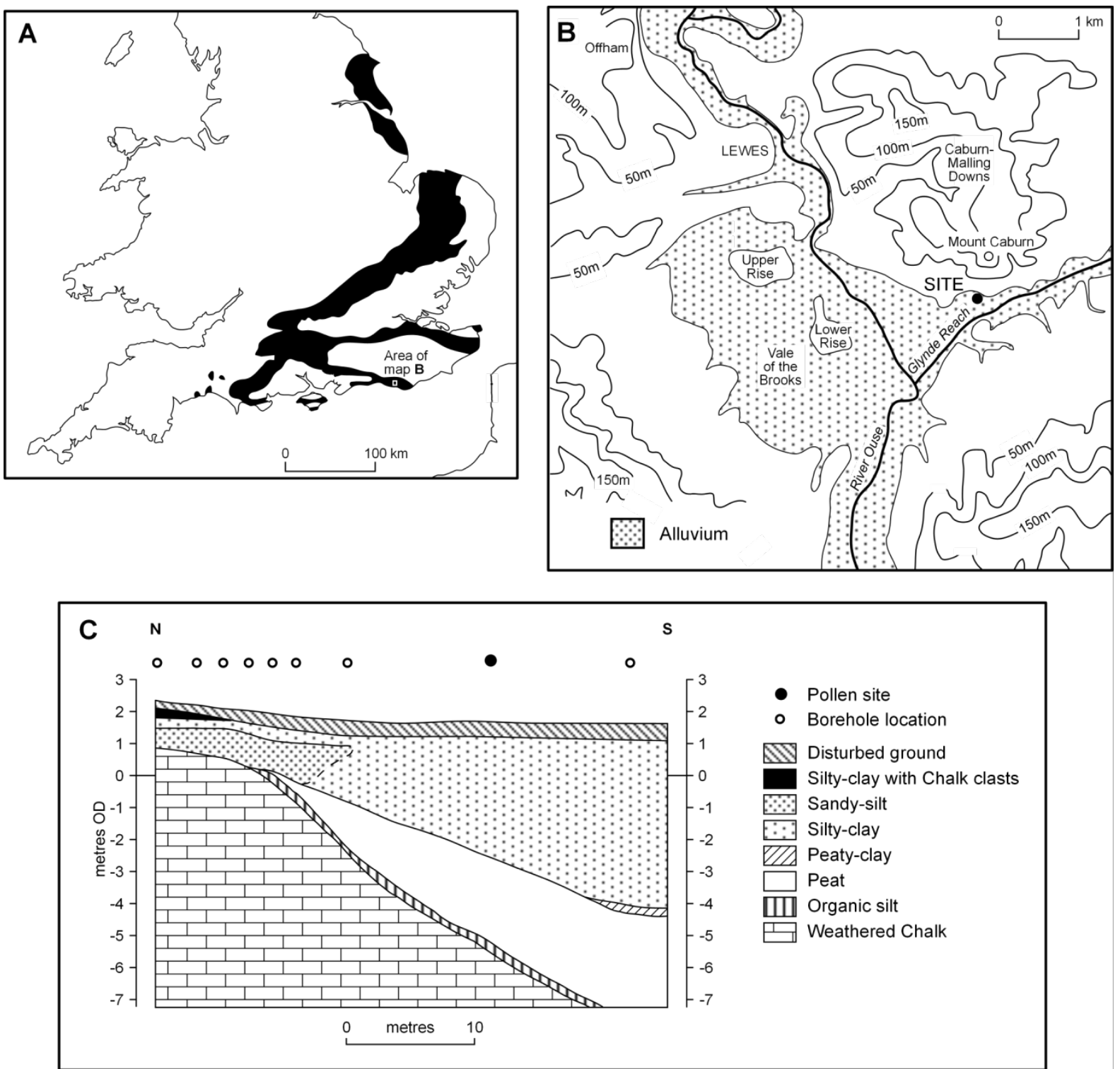
Figure 2 Macrofossil summary diagram: propagule numbers recovered, propagule numbers to a standardized volume $\left(40 \mathrm{~cm}^{3}\right)$, propagule accumulation rate, numbers of species present, moss abundance and loss-on-ignition values. Lithology follows Troels-Smith 1955.

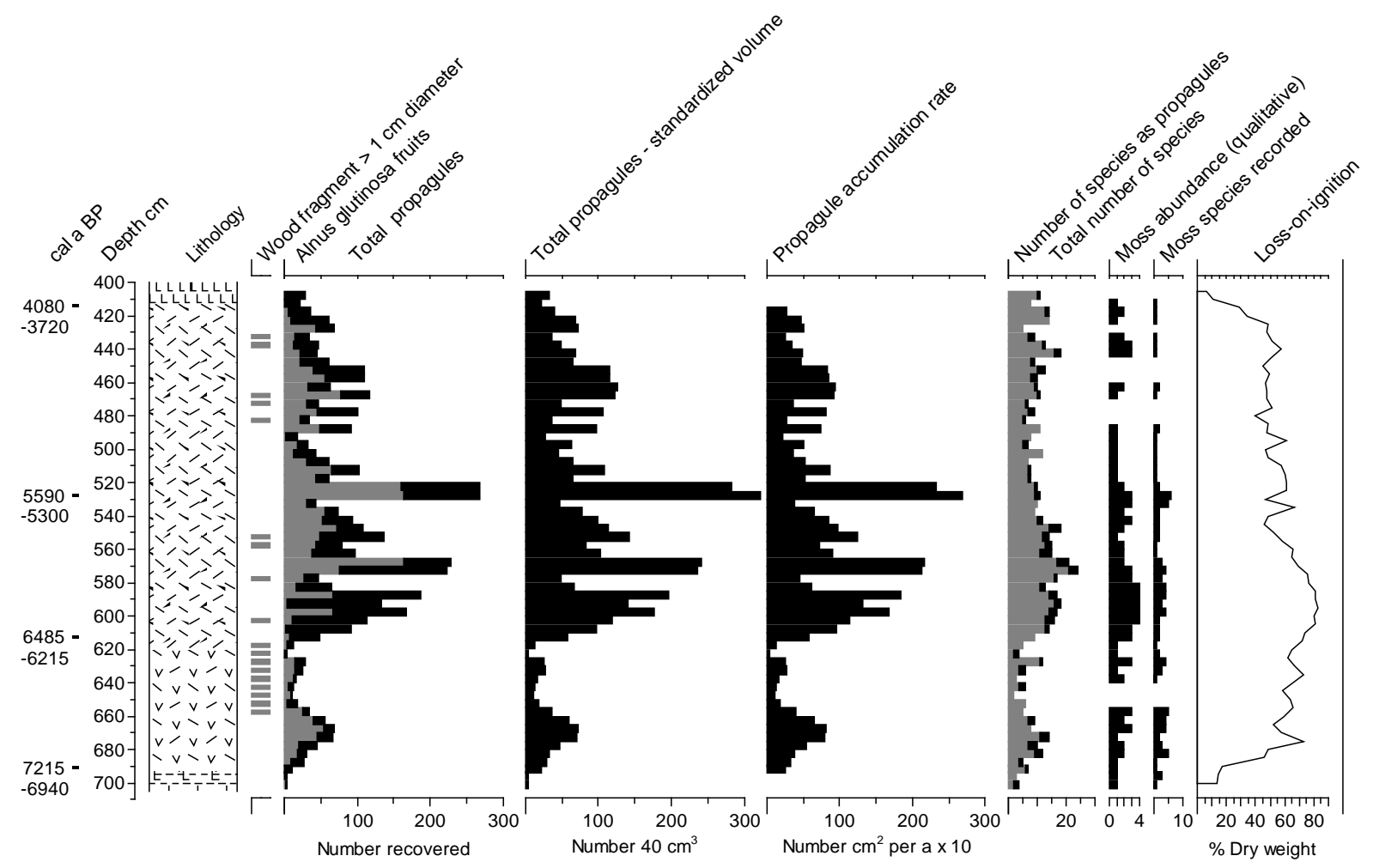


Figure 3 Comparison of the pollen and macrofossil data from the Caburn. (a) trees (b) small trees/shrubs and the Rosaceae (c) herbs, Cyperaceae and Poaceae (d) Juncaceae, aquatics and mosses. For the pollen data, with exception of Alnus (\% TLP), the \% TLP-Alnus values are shown as a continuous curve (with $\mathrm{x} 5$ exaggeration where necessary), the vegetative remains as a presence (closed circles) and the reproductive remains as numbers to a standardize volume $\left(40 \mathrm{~cm}^{3}\right) . \mathrm{C}=$ pollen clusters. As indicated, ordinal values are used to show moss representation. The zonation follows Waller and Hamilton (2000).
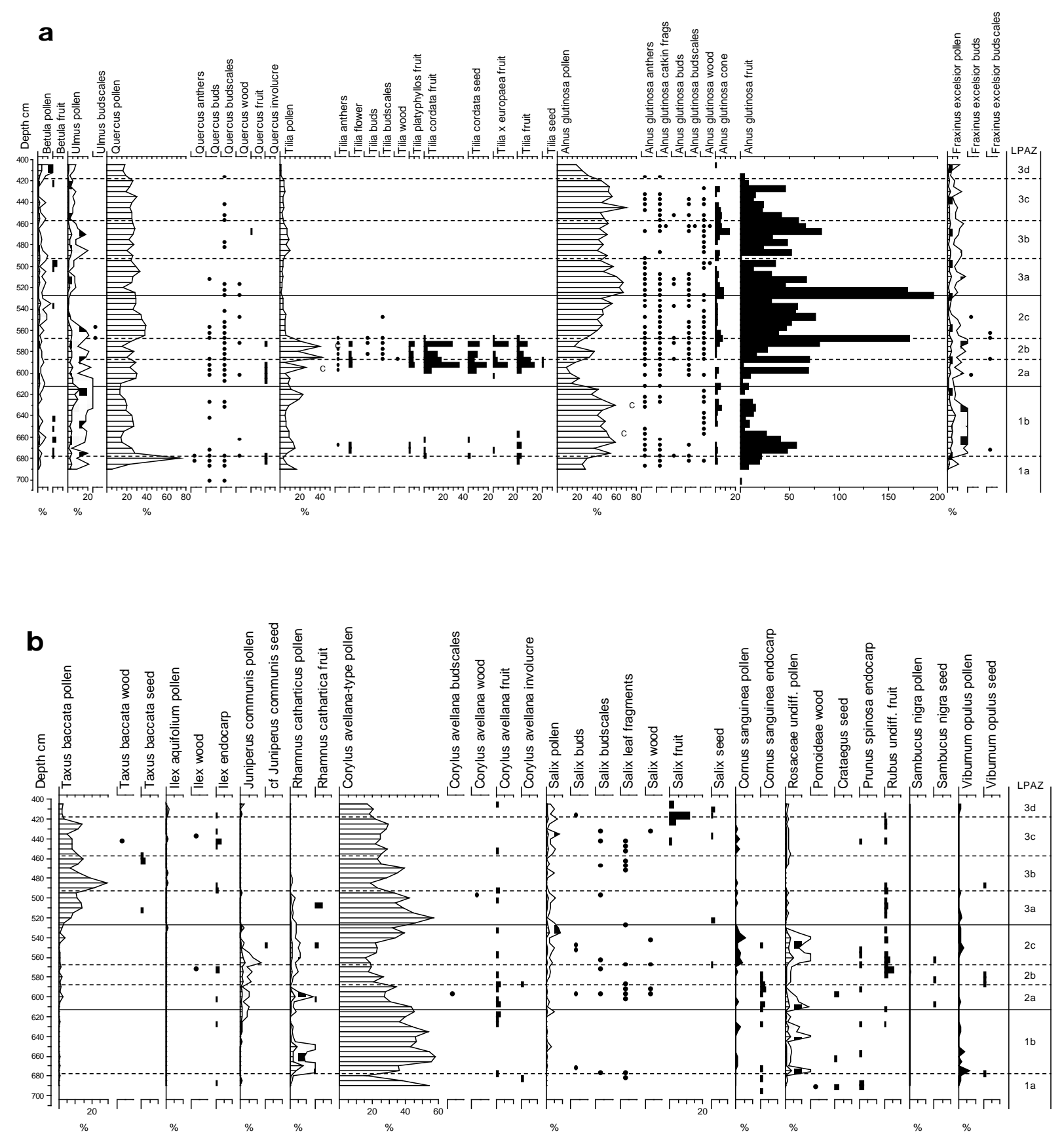

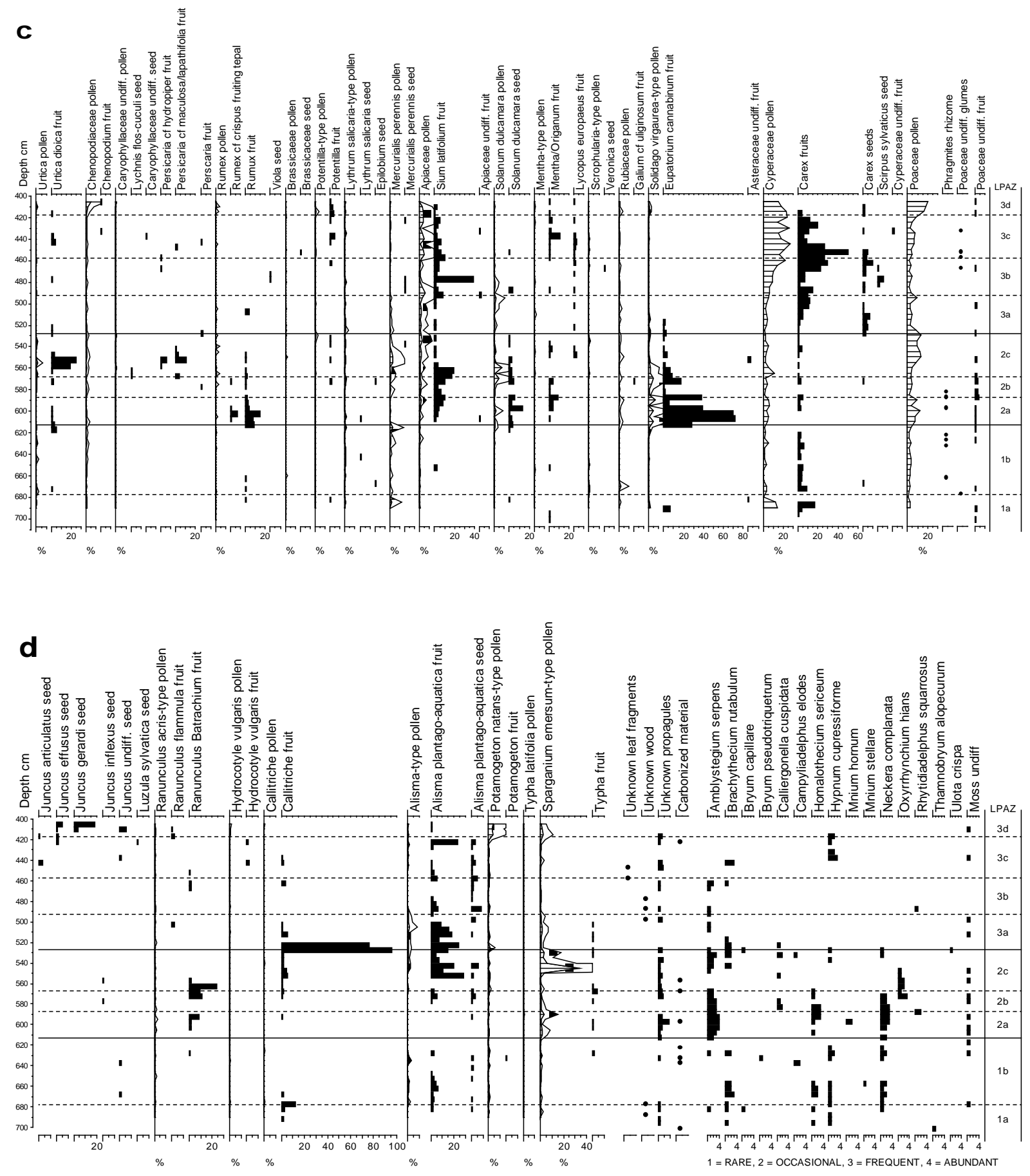
Table 1 Lithology of the core used for the pollen and macrofossil analyses. Notation follows Troels-Smith (1955).

\begin{tabular}{|c|c|}
\hline Depth & Lithology \\
\hline $\begin{array}{l}\text { above } 413 \mathrm{~cm} \\
(-2.54 \mathrm{~m} \mathrm{OD})\end{array}$ & $\begin{array}{l}\text { Bluish grey clayey silt } \\
\text { Nig. 2, Strf. 0, Elas. 0, Sicc. 2. Ag3, As1, Ga+, } \mathrm{Dg}^{+}, \mathrm{Th}^{2}+\text {, } \\
\text { Tm+ }\end{array}$ \\
\hline $\begin{array}{l}413-551 \mathrm{~cm} \\
(-2.54 \text { to }-3.92 \mathrm{~m} \mathrm{OD})\end{array}$ & $\begin{array}{l}\text { Brown slightly silty detrital peat } \\
\text { Nig. 3, Strf. 0, Elas. 0, Sicc. 2, Lim sup. 0. Dg3, Dh1, Dl+, } \\
\mathrm{Th}^{2}+\text {, Tb+, Ag+ }\end{array}$ \\
\hline $\begin{array}{l}551-620 \mathrm{~cm} \\
(-3.92 \text { to }-4.61 \mathrm{~m} \mathrm{OD})\end{array}$ & $\begin{array}{l}\text { Brown detrital peat } \\
\text { Nig. 3, Strf. 0, Elas. 0, Sicc. 2, Lim sup. 0. Dg3, Dh1, Dl+, } \\
\text { Tb+, } \\
\mathrm{Th}^{2}+, \mathrm{Ag}^{+}\end{array}$ \\
\hline $\begin{array}{l}620-693 \mathrm{~cm} \\
(-4.61 \text { to }-5.34 \mathrm{~m} \text { OD) }\end{array}$ & $\begin{array}{l}\text { Brown detrital peat with wood } \\
\text { Nig. 3, Strf. 0, Elas. 0, Sicc. 2, Lim sup. 0. Dg2, Dh1, Dl1, } \\
\text { Th }^{2}+\text {, Ag+ }\end{array}$ \\
\hline $\begin{array}{l}693-704 \mathrm{~cm} \\
(-5.34 \text { to }-5.45 \mathrm{~m} \mathrm{OD})\end{array}$ & $\begin{array}{l}\text { Transitional brownish grey organic silt } \\
\text { Nig. 2, Strf. 1, Elas. 0, Sicc. 2, Lim sup. 0. Sh2 Ag2, Dg+, } \\
\mathrm{Th}^{2}+, \mathrm{Gg}+\end{array}$ \\
\hline $\begin{array}{l}\text { below } 704 \mathrm{~cm} \\
(-5.45 \mathrm{~m} \mathrm{OD})\end{array}$ & $\begin{array}{l}\text { Greyish white silt with Chalk fragments } \\
\text { Nig. 1, Strf. 0, Elas. 0, Sicc. 1, Lim sup. 0. Ag3, Gg1 }\end{array}$ \\
\hline
\end{tabular}


Table 2 The mollusca and foraminifera recovered respectively from the base and top of the Caburn sequence.

\begin{tabular}{|l|l|l|l|l|l|}
\hline \multicolumn{1}{|c|}{ Species } & $\begin{array}{l}403-408 \\
\mathrm{~cm}\end{array}$ & $\begin{array}{l}408-413 \\
\mathrm{~cm}\end{array}$ & $\begin{array}{l}413-418 \\
\mathrm{~cm}\end{array}$ & $\begin{array}{l}693-698 \\
\mathrm{~cm}\end{array}$ & $\begin{array}{l}698-704 \\
\mathrm{~cm}\end{array}$ \\
\hline Mollusca & & & & 1 & 4 \\
\hline Discus rotundatus & & & & & 5 \\
\hline Clausilia bidentata & & & & & 1 \\
\hline Pomatias elegans & & & & & 1 \\
\hline Cochlicopa sp. & & & & & 2 \\
\hline Vitrea sp. & & & & & 7 \\
\hline $\begin{array}{l}\text { Carychium } \\
\text { tridentatum }\end{array}$ & & & & & 4 \\
\hline Carychium sp. & & & & & \\
\hline Aegopinella nitidula & & & & & \\
\hline Aegopinella pura & & & & & \\
\hline Trochulus hispidus & & & & & \\
\hline Foraminifera & & & & & \\
\hline Trochammina inflata & 10 & & & & \\
\hline Elphidium williamsoni & 126 & & & & \\
\hline
\end{tabular}


Supporting Information: Photographs of select plant macrofossil remains from the Caburn

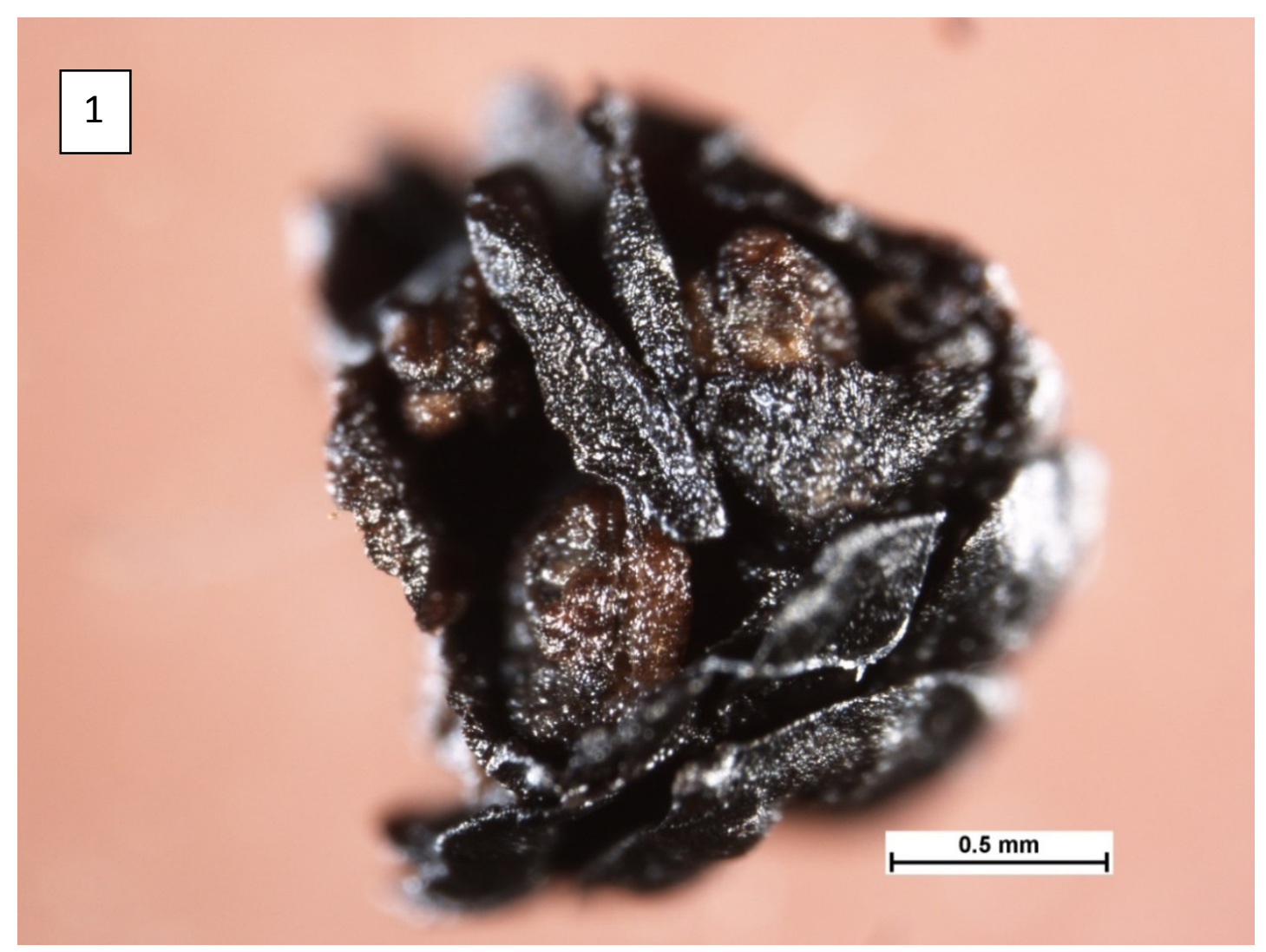

1. Alnus glutinosa catkin fragment showing in situ anthers 


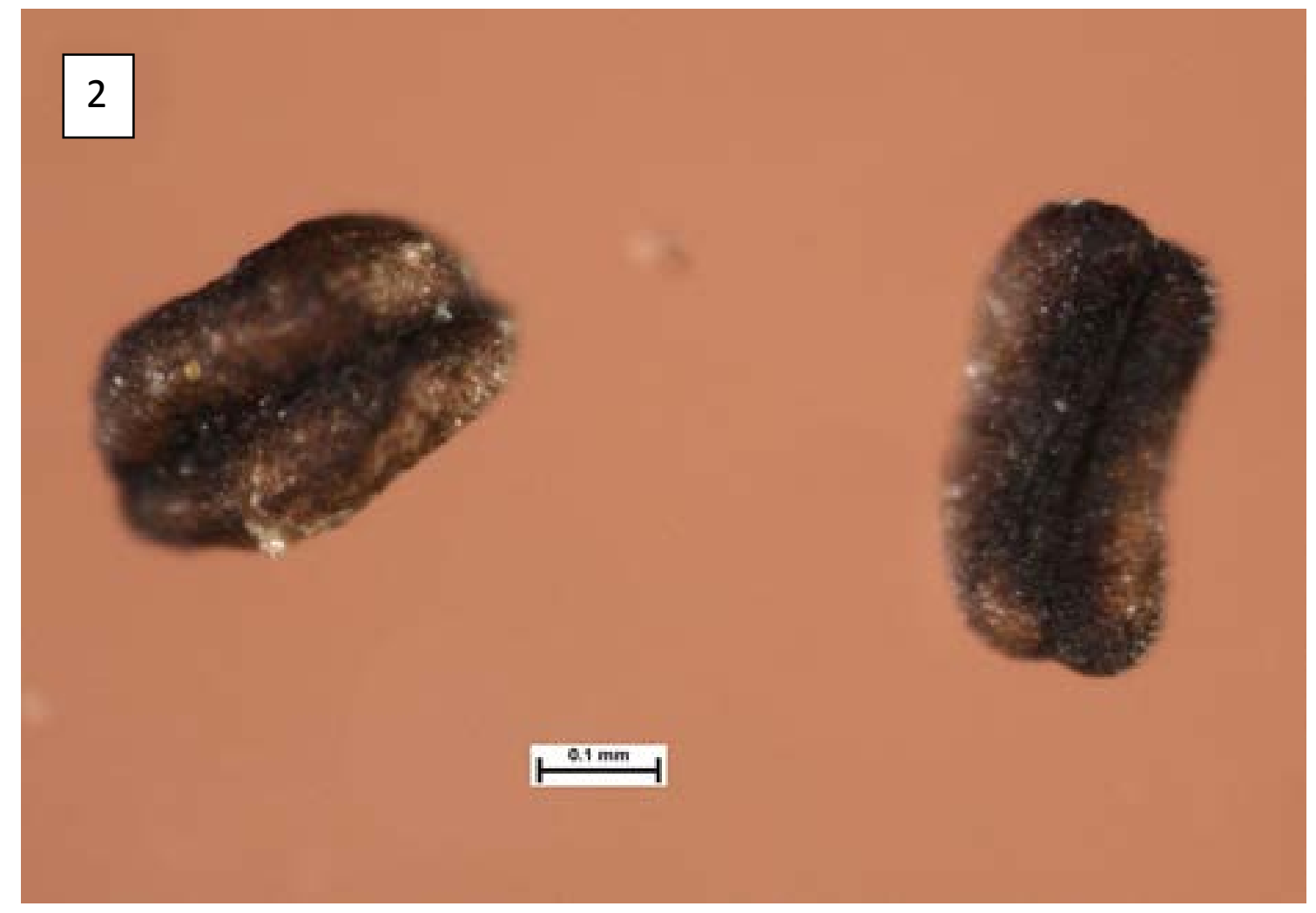

2. Alnus glutinosa anthers

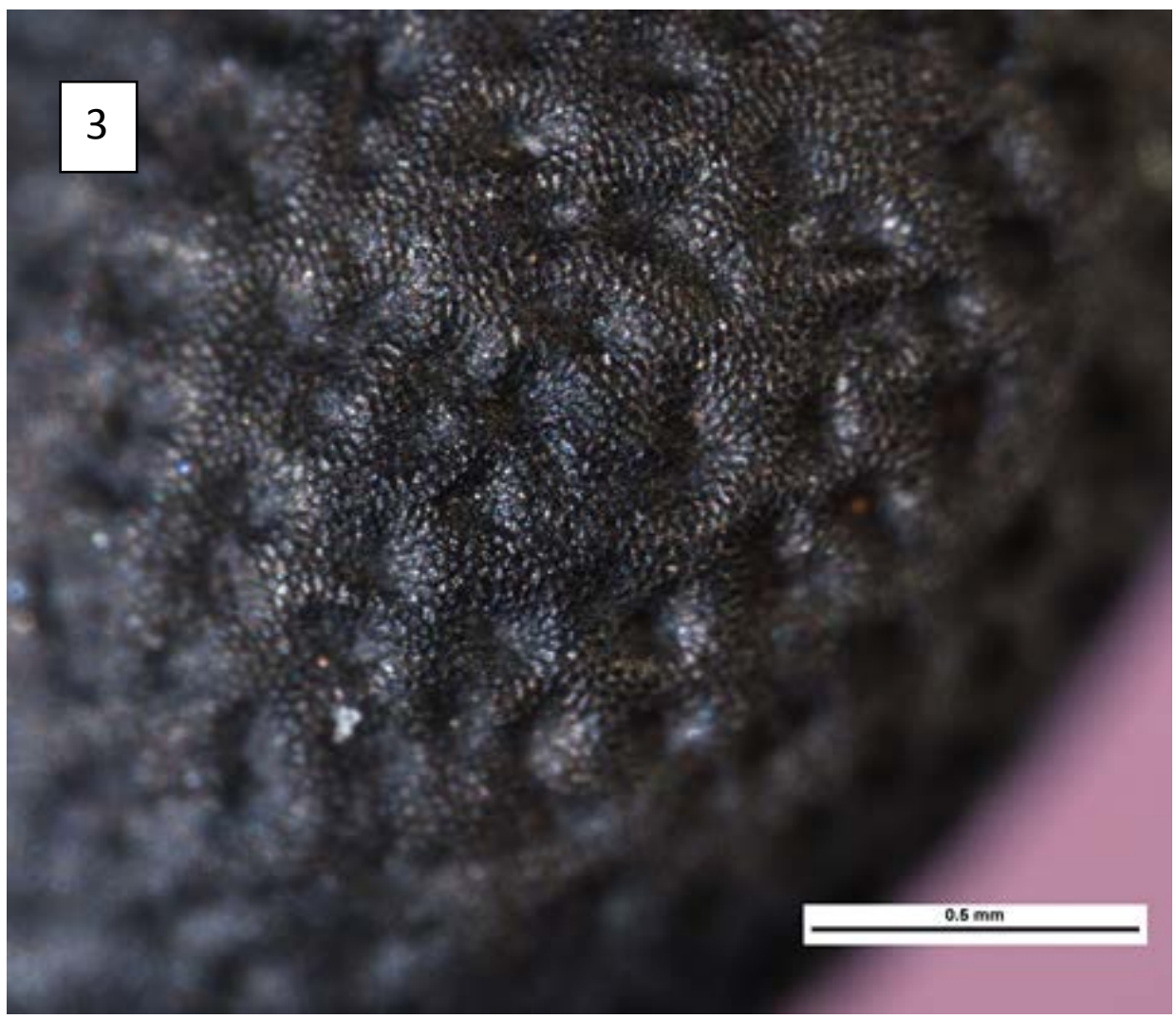

3. Mercurialis perennis seed: detail of sculpturing pattern (not shown in most seed illustration guides) 


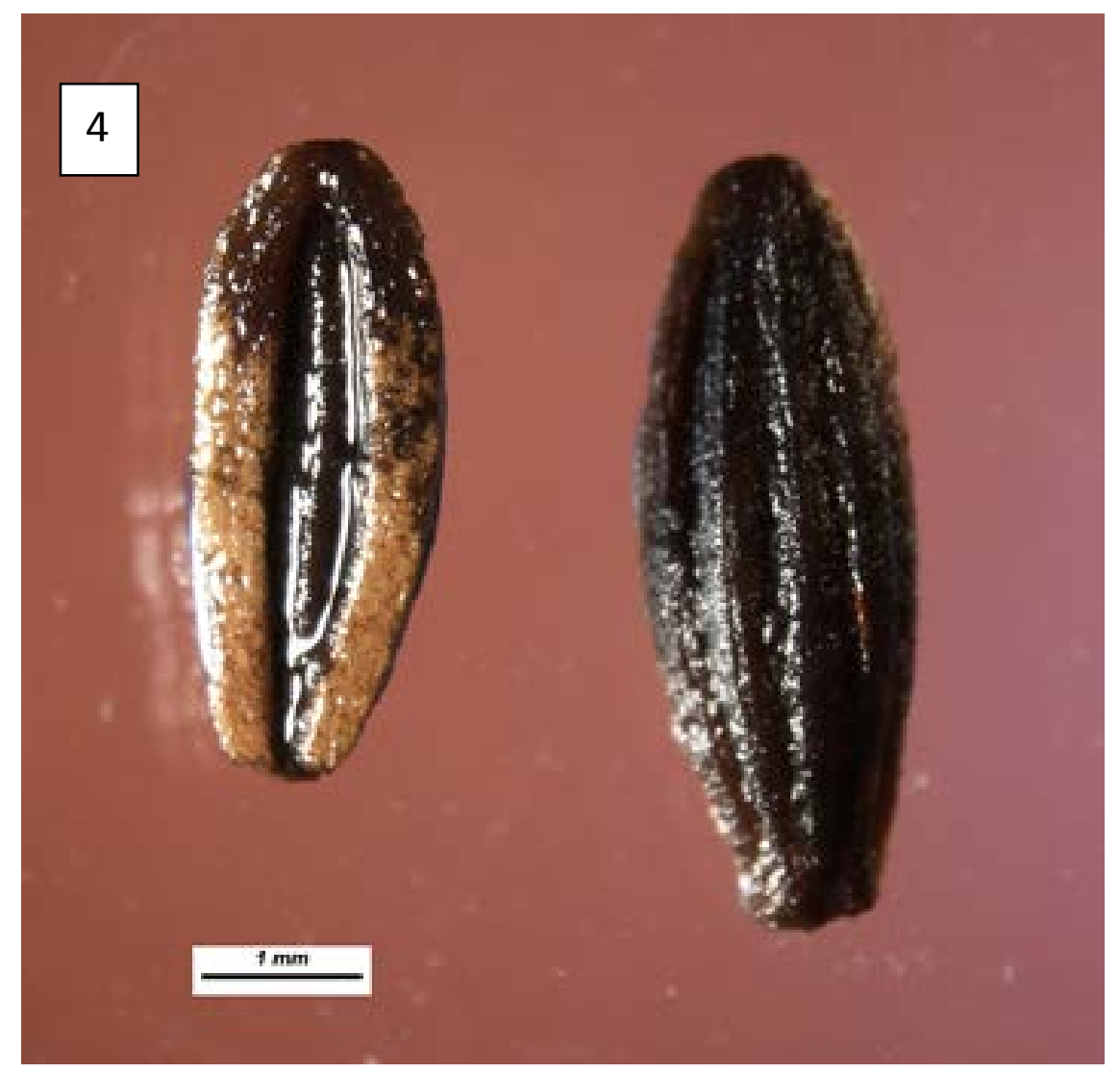

4. Sium latifolium fruit

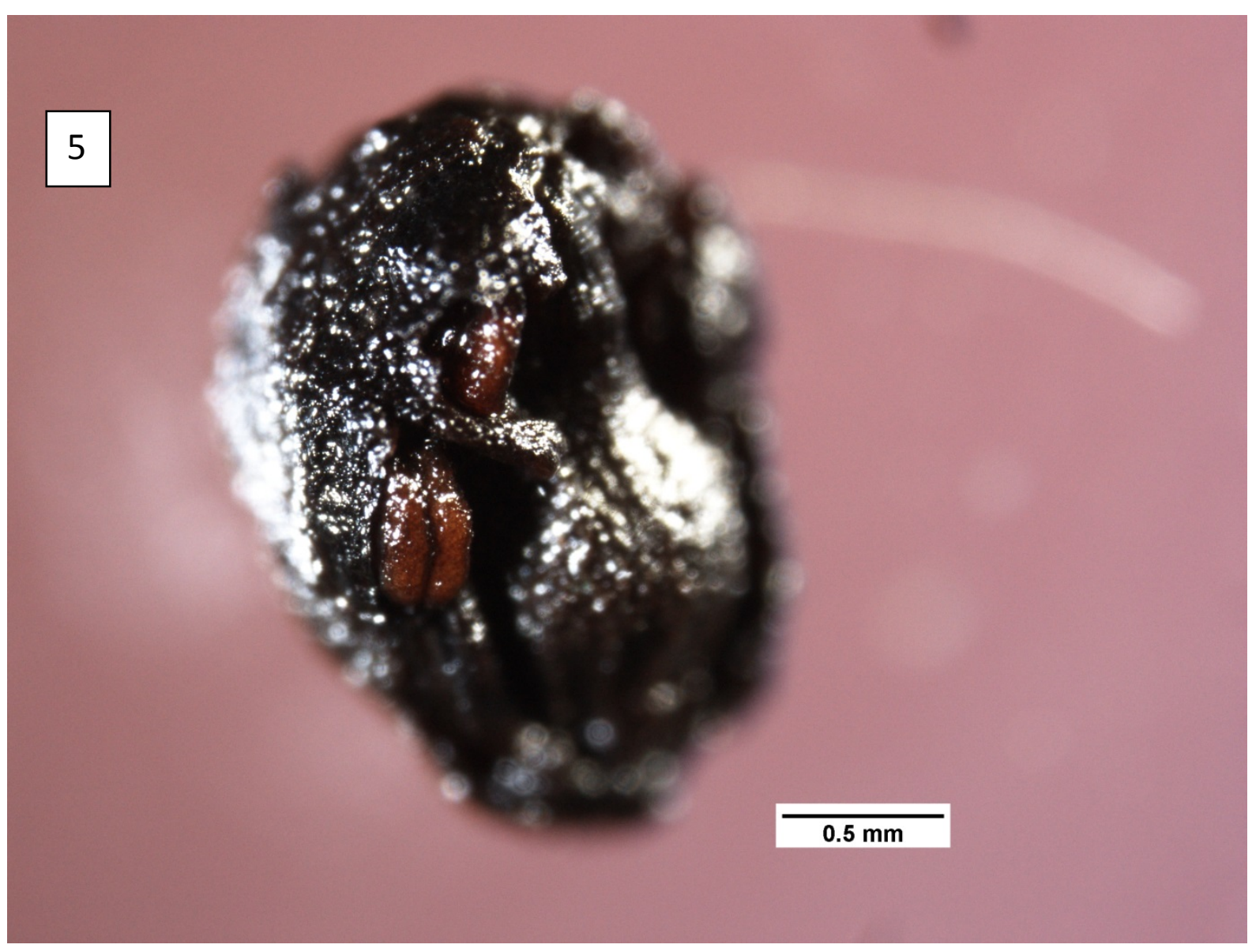


5. Tilia 'flower'. The anthers and the edge of the ovary and style are visible

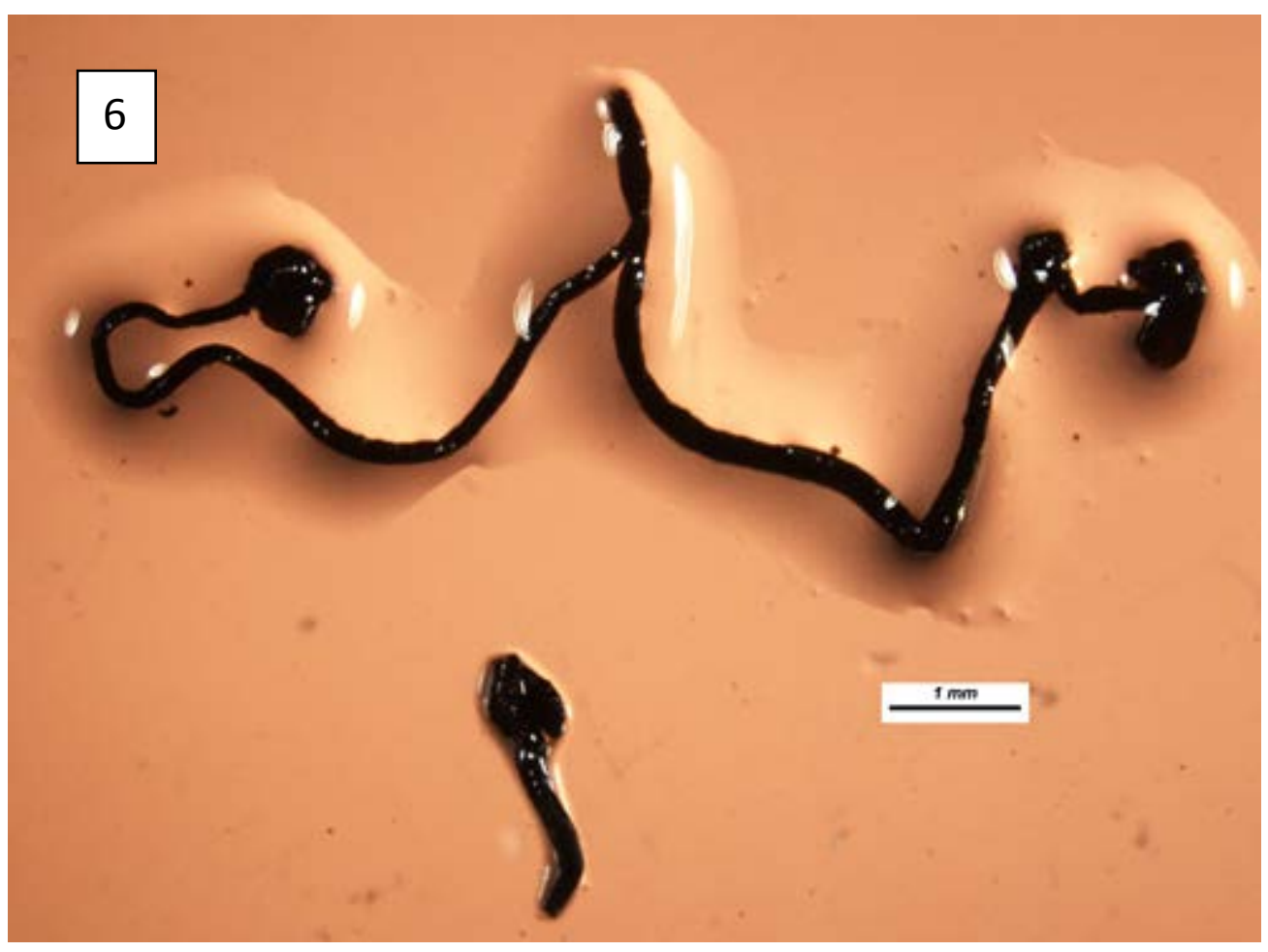

6. Tilia stamens

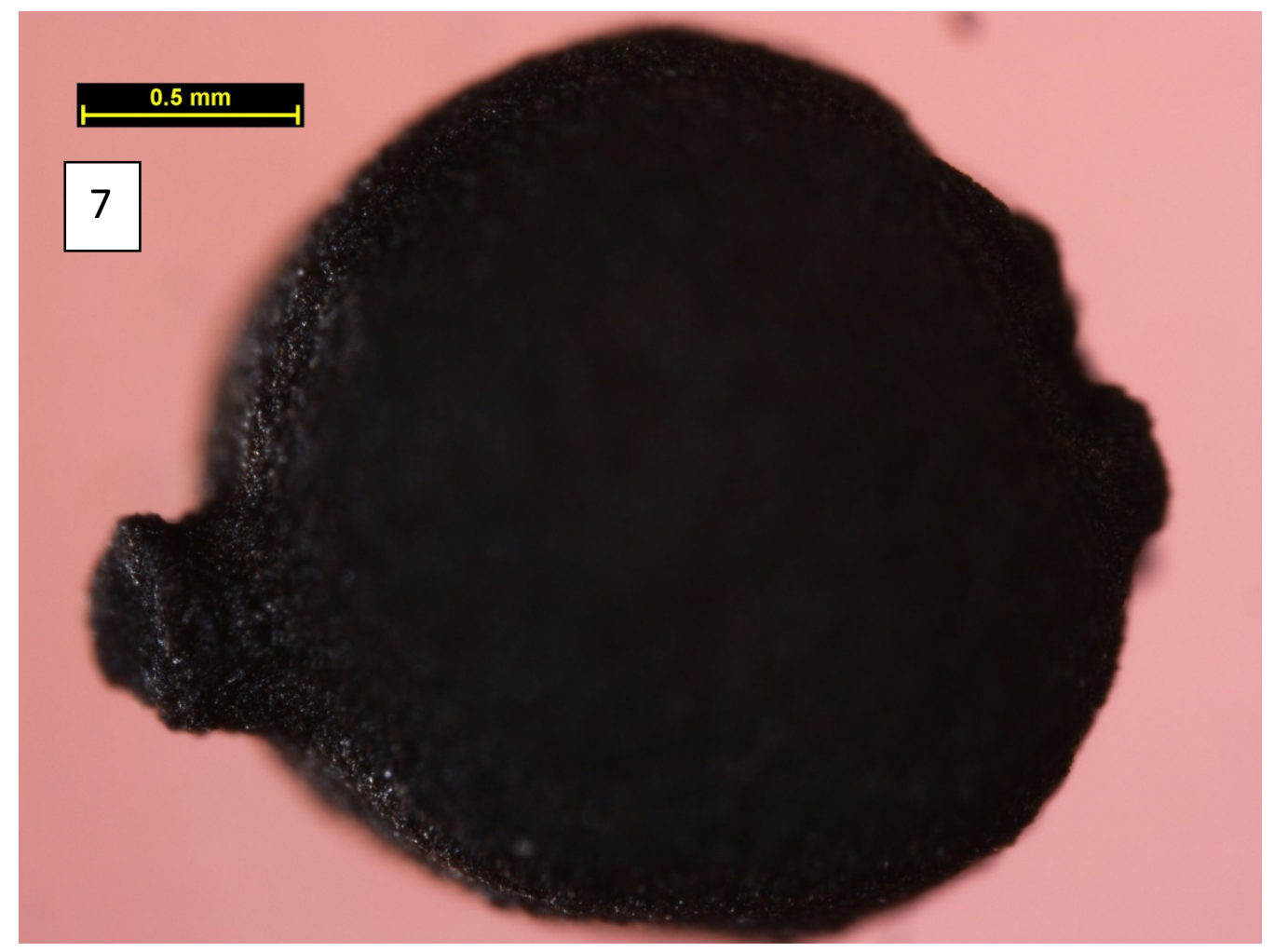

7. Tilia cordata fruit 


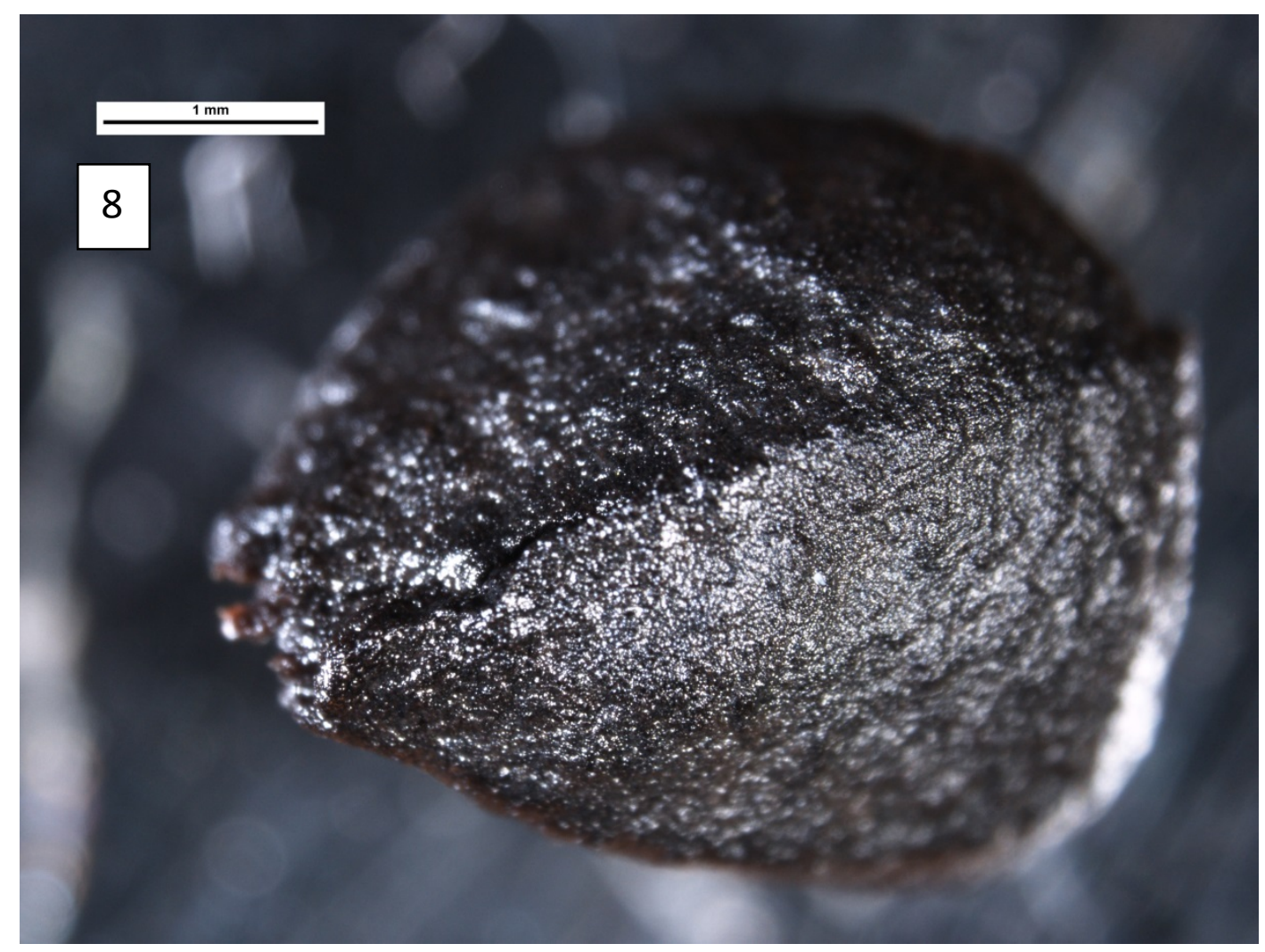

8. Tilia platyphyllos fruit showing rib 